\title{
O FOTOJORNALISTA NO ATO SOCIAL DA PRODUÇÃO DE NOTÍCIAS
}

\author{
Luzo Vinicius Pedroso Reis ${ }^{1}$ \\ Fábio Henrique Pereira ${ }^{2}$
}

\section{Introdução}

Este relato etnográfico descreve e analisa, a partir da perspectiva do interacionismo simbólico e dos mundos sociais desenvolvida particularmente por Becker (1974a) e Strauss (1978), a rotina de um dia de trabalho do fotojornalista Pedro Ladeira, do jornal Folha de S. Paulo. A partir de uma abordagem etnográfico-qualitativa e com suporte das sociologias visual e do trabalho, observamos a atuação desse profissional em alguns espaços de poder político da cidade de Brasília: o Supremo Tribunal Federal (STF), a praça dos Três Poderes, comissões e comitê de imprensa da Câmara dos Deputados. Entendendo o ato social da confecção e publicação de notícias, o que chamamos de jornalismo, enquanto uma prática coletiva (Pereira, 2018), a perspectiva do mundo social abre nosso campo de observação para investigar a participação de atores que em outras abordagens poderiam ser considerados menos relevantes na produção da informação. É nesse sentido que esse ensaio verificou a atuação de um fotojornalista para perceber de que forma este profissional parece ganhar relevância na conjuntura contemporânea do jornalismo.

Obter os dados de análise a partir da observação participante e de conversas informais com o profissional foi importante para perceber as minúcias das negociações e os atores que mais influenciam e participam de sua rotina. Por isso, verificou-se que a “descoberta e o estudo de cada subprocesso e suas relações, incluindo relações conflituosas e de poder, são partes essenciais na pesquisa de mundos sociais." (Strauss, 1978: 122)"3. Se o jornalismo é, então, um trabalho coletivo, é preciso entender as formas convencionais de

Universidade de Brasília, Brasil. E-mail: 1uzoreis@gmail.com

2 Universidade de Brasília, Brasil. E-mail: fabiop@unb.br

3 Do inglês original: "The discovery and study of such subprocesses and of their relationships, including conflictual and "power" relationships, are essential parts of research into social worlds". (Tradução dos autores) 
articulação entre os atores desse mundo social. Como operam e negociam pessoas tão distintas como repórteres, fontes, fotojornalistas, editores, diagramadores e tantos outros atores que, embora a princípio não pareçam ter nenhuma relação como ato social da produção de notícias, integram de maneira decisiva esse mundo social? Foi a partir de uma pesquisa de caráter etnográfico que observamos, por exemplo, o papel fundamental dos profissionais de segurança para atividade do fotojornalista Pedro Ladeira, que integra o que Becker (1982) chama de "rede de colaboradores" (networking of collaborating people) desse mundo.

Tal coordenação só é possível a partir da existência de um sistema de convenções que é compartilhado pelos diversos atores desse mundo social. Para Becker (1974), as convenções referem-se a sistemas de códigos compartilhados pelos atores envolvidos na produção de um ato social de modo a coordenar as ações e facilitar a tomada de decisões. Tal sistema impõe constrangimentos e restrições aos atores e estão colocados nas relações e negociações das quais participa. Em se tratando de produção de notícias, o valor-notícia, ou seja, saber o que possui ou não valor para ser noticiado, é uma das principais convenções, compartilhada por boa parte dos atores envolvidos nesse mundo social. Em nossa observação verificamos como esse sistema convencional é compartilhado por atores tão diversos quanto os próprios seguranças que atuam lidando com autoridades e profissionais de imprensa. Também pudemos observar de que forma o domínio do sistema de convenções pelo fotojornalista Pedro Ladeira lhe permite tomar decisões de forma ágil, como no processo de seleção de imagens, lhe dando autonomia e respaldo.

\section{A precarização do jornalismo}

Este ensaio etnográfico se insere em um contexto de precarização da profissão de jornalista, marcada pela redução do quadro de pessoal ${ }^{4}$, pelo predomínio por formas precárias e flexíveis de contratação, pelo descumprimento de pagamento do piso salarial, pela desobediência à jornada de trabalho diária estabelecida para a categoria (Lelo, 2019;

4 Dados do projeto Passaralho falam em 2.327 demissões de jornalistas em redações entre 2012 e 2018. Disponível em: http://passaralhos.voltdata.info/. Acesso em 22 jan. 2020.

Iluminuras, Porto Alegre, v. 21, n. 52, p. 310-340, abril, 2020. 
Nicoletti e Mick, 2018). Nesse cenário, os jornalistas (incluindo os fotojornalistas) são pressionados por critérios de produtividade, traduzidos muitas vezes pelo aumento do número de pautas a serem cobertas ao longo do dia e o acúmulo de tarefas a serem desenvolvidas por um mesmo profissional (multitasking).

Esse conjunto de mudanças que afetam o mundo do trabalho no jornalismo (Figaro, 2013) é particularmente relevante no caso do veículo Folha de S. Paulo. Trabalhos mais específicos sobre os processos de reestruturação e convergência da Folha (Cf. Kischinhevsky, 2010; Pereira e Kalume Maranhão, 2014; Renault, 2013) apontam para um contexto marcado pela redução de estrutura e o corte de pessoal, incluindo nas sucursais. Algumas funções - como a de motorista (Moretzsohn, 2011) - foram praticamente extintas. Além disso, com a integração das redações, os conteúdos das versões impressa e on-line do jornal passaram a ser alimentadas pela mesma equipe de jornalistas.

Do ponto de vista de uma sociologia interacionista do trabalho, essas transformações afetam não só a "qualidade" do produto jornalístico (Nicoletti e Lima, 2018; Becker, 2009), mas levam à uma reconfiguração das formas convencionais de colaboração entre os diferentes atores e segmentos do mundo social, reconfigurando os processos de divisão do trabalho. Além disso, incidem sobre as carreiras jornalísticas na medida em que a precarização afeta a capacidade dos atores de construírem um planejamento de longo prazo em um contexto marcado pela incerteza em relação ao futuro da profissão (Goyanes e Rodríguez-Gómez, 2018; Menger, 2009).

Além dessas transformações gerais que dizem respeito ao trabalho das equipes de jornalismo como um todo, é interessante observar no caso específico do fotojornalista como as mudanças no estatuto da imagem fotográfica parecem desempenhar um papel importante para entendermos a complexidade de seu processo de precarização. Ao longo de todo o século XIX e início do século XX havia uma forte ideia de que a fotografia era o resultado de uma máquina capaz de fixar as aparências do mundo de forma objetiva em benefício da memória (BAUDELAIRE, 1859), sendo vista como uma espécie de "espelho do real" (ROUILLÉ, 2009:189), ou seja, uma cópia fiel da realidade produzida pelo contato direto entre a câmera e mundo. Já ao longo do século XX diversos expedientes ampliam as possibilidades da imagem fotográfica por entendê-la não mais, ou não apenas, como produto de uma técnica de automatização da fabricação de imagens, mas como uma 
construção imagética fruto também de um olhar capaz de construir representações, narrativas e, portanto, de comunicar sentidos a partir de escolhas técnicas e formais.

$\mathrm{Na}$ imprensa, podemos destacar o papel fundamental que as revistas ilustradas, a partir da virada do século XIX para o XX, tiveram nessa mudança ao elevar o papel que as fotografias e os fotógrafos desempenhavam em suas publicações. Essas mudanças se traduziam no aumento de fotografias publicadas por matéria em contraposição às ilustrações e às fotos únicas da imprensa tradicional - instituindo a chamada série fotográfica (photo series) -, a prevalência que muitas vezes era dada à imagem em relação ao texto (com muitas matérias trazendo fotografias em grandes formatos ou páginas duplas), além do aumento do papel dos fotógrafos que tinham nessas revistas maior liberdade de produção e de edição de seu trabalho. Destacam-se entre essas publicações as pioneiras alemãs Berliner Illustrierte Zeeitung - BIZ, (1892-1945) e Müncher Illustrierte Presse (1923-1944); a americana Life (1936-2000); a francesa $V u$ (1928-1940); a inglesa Picture Post (1938-1957); as brasileiras Cruzeiro (1928-1975) e Realidade (1966-1976) entre muitas outras em diversas partes do mundo. Em suma, havia nesses periódicos uma valorização do papel da imagem fotográfica em relação ao texto escrito. Podemos entender isso como um novo estatuto da imagem fotográfica na imprensa: não mais o produto passivo de uma técnica que cumpriria uma função menor, no sentido de que apenas ilustraria o texto escrito, mas uma importante fonte narrativa acerca dos assuntos que por si só era capaz de produzir sentido, podendo, obviamente, complementar ou ser complementada pela informação textual.

Essas mudanças refletem aquilo que a autora e pesquisadora brasileira Susana Dobal enxerga como uma mudança de paradigma da imagem fotográfica. Segundo a autora, essas mudanças integram um "cenário bem mas fluido" (DOBAL, 2012: 2) para a fotografia, em que ela "perdeu o status de verdade última mas ganhou a possibilidade de revelar verdades múltiplas e provisórias" (ibidem: 2). Reflexão em linha com o que o pesquisador português da história do fotojornalismo Jorge Pedro Sousa identifica como a passagem de um "reino da verdade" para um "reinado do credível" (2004: 9), se referindo às mudanças nas práticas do fotojornalismo. A importância do papel do fotojornalista na rotina dos veículos de comunicação aumenta sobremaneira uma vez que este deixa de ser um técnico responsável pelo mero acionamento de uma máquina que reproduz 
objetivamente a realidade, a fim de corroborar ou atestar o argumento escrito do jornalista, para assumir o papel ele próprio de um narrador ${ }^{5}$. Em sua tese que analisa o surgimento e a evolução do gênero documental na fotografia, Castanheira (2017) identifica as revistas ilustradas como um ponto fundamental na consolidação desse gênero. Para o autor, foram nessas revistas que foi possível aos fotógrafos alcançarem o status de grandes celebridades que viajavam pelo mundo produzindo narrativas visuais. De fato, nomes importantes para a fotografia de imprensa como o do norte-americano W. Eugene Smith (1918-1978) ou do húngaro Robert Capa (1913-1954) ganharam seus status a partir de suas impactantes publicações em revistas como a Life ${ }^{6}$.

É salutar observar, contudo, que com a periodicidade mais espaçada das revistas, mais tempo e recursos para viagens, além da possibilidade de dedicação integral a projetos específicos, esses fotógrafos possuíam uma rotina muito distinta daqueles profissionais empregados exclusivamente na imprensa diária, nomeadamente nos jornais impressos. A possibilidade de criação de narrativas visuais nos periódicos produziu um tipo diverso de prática, a chamada fotorreportagem, como lembra Castanheira ${ }^{7}$ (ibidem, p: 116). De fato, o potente estatuto narrativo da imagem fotográfica, consolidado na experiência das revistas ilustradas, promoveu uma distinção entre a prática daqueles profissionais empregados nos

5 Ou um "criador-fotógrafo" dirá Jorge Pedro Sousa. Segundo o autor, os fotojornalistas passaram a olhar "para si mesmos como participantes num jogo que há muito deixou de ser um mero jogo de espelhos, para desembocar no jogo bem mais elaborado e complexo dos mundos de signos e códigos, de linguagem e de cultura, de ideologia e de mitos, de história e tradições, de contradições e convenções”. (Ibidem: 10)

6 Algumas das grandes reportagens de W. Eugene Smith publicadas na revista Life foram Country Doctor (1948), Nursy Midwife (1951) e o célebre ensaio Death-Flow from a Pipe (1972) sobre a contaminação por mercúrio da comunidade industrial de Minamata, no Japão. Seus ensaios fotográficos possuiam forte conotação humanista e eram produzidos ao longo de meses de convívio com as pessoas envolvidas em seus temas. Além da confiança desenvolvida com seus personagens, chama a atenção no trabalho de Smith a profunda qualidade estética e narrativa de suas imagens. Em Minamata Smith produziu uma das mais belas e impactantes fotos já publicadas na imprensa: Tomoko Uemura in her bath retrata uma mãe dando banho em sua filha deformada pela contaminação, uma cena forte que certamente exigiu todo um trabalho e tempo de produção do fotógrafo. De Robert Capa, conhecido como um dos mais famosos e intrépidos fotógrafos de Guerra, podemos destacar a publicação sobre o dia em que as tropas aliadas desembarcaram na França, o dia D, episódio marcante da 2 guerra Mundial, publicada pela Life em 1944.

7 Apesar da fotorreportagem muitas vezes ser também chamada de fotografia documental, aprendemos a partir de Castanheira (Op. Cit), Rouillé (Op. Cit), Lombardi (2007) e outros que o documental não se resume a reportagem. Sobretudo se considerarmos que projetos documentais podem possuir um caráter bastante pessoal não se limitando às restrições e constrangimentos impostos por veículos de comunicação. Por conta dessa liberdade que diz respeito a escolha de temas, escolhas formais, assunção de posturas ideológicas diversas, maior liberdade de tempo de produção e outras houve uma enorme aproximação da fotografia documental com o universo das artes, não sendo incomum hoje a presença dessas imagens em galerias, livros e museus. 
jornais e dos que trabalhavam para agências e revistas, embora ambos continuassem sendo muitas vezes chamados de fotojornalistas.

Também é importante dizer que o sucesso das fotografias nessas revistas alterou o nível de expectativas da fotografia na imprensa como um todo. Com o tempo, mesmo os veículos mais tradicionais passaram a demandar fotografias mais criativas que explorassem a capacidade de sugestão e de criação narrativa da imagem fotográfica. Evidentemente que essa demanda teve que observar os limites de tempo para a produção fotográfica em virtude do número maior de pautas que a cobertura diária exige, além das restrições editoriais e de número de fotografias que poderiam ser publicadas em uma edição de jornal. Fatores não encontrados nas redações de revistas ilustradas como a Life e que seduziram os melhores fotojornalistas a trabalharem em periódicos, agências especializadas ou mesmo desenvolverem projetos pessoais de documentação fotográfica.

Como veremos na observação de campo com o fotojornalista Pedro Ladeira, essa situação parece ganhar novos contornos hoje. Sua rotina como fotojornalista de um jornal diário nos dá uma pista de como a adequação à redução de quadros e outros sintomas da atual configuração do trabalho no jornalismo de modo geral, e na Folha de S. Paulo em específico, tem sido realizada. Por um lado, as exigências que novas plataformas do jornalismo on-line e as próprias redes sociais impõe aos veículos de comunicação pressionam cada vez mais por imagens criativas e narrativas visuais de impacto, algo que por algum tempo era mais comum às reportagens veiculadas por periódicos especializados. Por outro lado, a falta das condições materiais já mencionadas tornam a função do fotojornalista ainda mais desafiadora. Cria-se um território renovado para este profissional onde convenções são reconfiguradas em meio ao processo mais amplo da precarização do trabalho.

\section{Observação de campo e sociologia visual}

Este ensaio se baseia em uma abordagem etnográfica. Nela, duas fontes de dados são utilizadas. A primeira é proveniente das notas de campo produzidas por um dos autores por meio da observação de um dia de trabalho do fotojornalista da Folha de S. Paulo Pedro 
Ladeira, em 25 de junho de 2019, na cidade de Brasília. A segunda fonte são algumas das próprias fotografas produzidas por Ladeira. A observação foi feita por um dos autores que também é fotógrafo, o que facilitou o acesso ao campo e capacidade de um registro mais aproximado das convenções do trabalho fotojornalístico. A aproximação com Pedro Ladeira foi realizada por meio de contatos com outros fotojornalistas da cidade de Brasília que, por ser a capital política do país, concentra um grande número de profissionais de imprensa. Como mostra a descrição de campo, a observação permitiu o registro de várias situações de interação entre o sujeito da pesquisa e atores dos mundos da política e do jornalismo. Isso inclui ainda sua relação com os dispositivos técnicos (câmeras, objetivas, etc.) utilizados no seu trabalho. Ao longo da observação, o fotojornalista também relatou eventos da sua experiência biográfica que foram consideradas na análise.

Sobre as fotografias de Pedro Ladeira produzidas no dia da observação e cedidas aos autores, adotamos a proposta de Howard Becker (1974b) do uso da fotografia por cientistas sociais como formas de coleta, registro e apresentação de dados e produção de conclusões:

Cada parte da imagem fotográfica traz alguma informação que contribui para o enunciado em sua totalidade; a responsabilidade do leitor é ver, no sentido mais literal que existe, e responder a isso. Dito de outra forma, o enunciado que a imagem produz - não apenas o que ela mostra, mas o estado de espírito, as avaliações morais e as conexões causais que ela sugere - é construído a partir desses detalhes ${ }^{8}$ (Becker, 1974b:7).

O uso de fotografias neste ensaio tem dupla função. Por um lado, revela a forma como Pedro Ladeira negocia sua subjetividade como fotógrafo com o conjunto mais amplo de convenções do mundo dos jornalistas, e que definem formas aceitáveis de representação dos eventos jornalísticos. Por outro, revelam a forma como o fotojornalista lida com os constrangimentos da cobertura e as escolhas e negociações às quais ele será submetido nas diferentes situações de interação.

Cabe ressaltar que o uso da sociologia visual em um trabalho etnográfico se justifica por três razões. Primeiro, do ponto de vista de nossa coerência teórica, ela se insere

8 Do inglês original: "Every part of the photographic image carries some information that contributes to its total statement; the viewer' s responsibility to see, in the most literal way everything that is there and respond to it. To put it in another way, the statement the image makes - not just what it shows you, but the mood, moral evaluations and causal connections it suggests - it built up from those details". (Tradução dos autores) 
em uma proposta beckeriana de constituição de uma sociologia das modalidades de representação da sociedade (como o fotojornalismo) (Becker, 2009). Busca-se, neste caso, confrontar a fotografia às diferentes situações de interação que estão na origem desse tipo de representação. Além disso, o uso da sociologia visual permite recuperar parte da materialidade do trabalho jornalístico, revelando não só os atores implicados nessa atividade, mas os espaços nos quais eles atuam e os objetos que fazem parte dessa prática. Assim, esse procedimento permitiria "uma compreensão das restrições e flexibilidades com as quais os jornalistas foram forçados a conviver durante a vida cotidiana do trabalho, bem como o ambiente espacial do jornalismo foi imaginado por outros e contém fundamentos ideológicos" (Le Cam, 2015: 135) ${ }^{9}$. Nesse sentido, uma leitura mais sociológica desse processo permitiria revelar indicadores relevantes do ponto de vista do trabalho e da identidade dos jornalistas.

Assim, Combinar observação e sociologia visual permitiu não só descrever as convenções e interações que perpassam o trabalho do fotojornalista - visto, portanto, como uma prática coletiva inserida no contexto mais amplo de um mundo social - como possibilitou explorar as formas convencionais de representação da sociedade que emergem dessa prática. Esse cruzamento metodológico se apresenta como uma contribuição original deste artigo - mais do que os próprios resultados, baseados na observação de curta duração de um único caso.

\section{Descrição do campo}

Nesta seção, faremos uma breve descrição do campo, com base nas notas feitas pelo Autor 1 deste ensaio, no dia 25 de junho de 2019. Respeitando as condições de

9 Do inglês original: "an understanding of the constraints and flexibilities that journalists had been forced to live with during their daily work lives, as well as how the spatial environment of journalism has been imagined by others and contains ideological underpinnings". (Tradução dos autores) 
realização da observação e registro do campo, manteremos o relato na primeira pessoa do singular. $^{10}$

Encontrei Pedro Ladeira às $14 \mathrm{~h} 15$ no prédio do anexo II do Supremo Tribunal Federal (STF). Havia uma grande fila de advogados e jornalistas se credenciando para entrar, eu iria me cadastrar como assistente de Ladeira. No $4^{\circ}$ andar do prédio estava para começar a sessão de apelação da defesa do ex-presidente Luís Inácio Lula da Silva, que pedia sua soltura sob o argumento de suspeição do juiz do caso, Sérgio Moro. Apesar de ter sido impetrado pela defesa de Lula no final de 2018, a solicitação ganhou maior relevância em face das recentes reportagens publicadas pelo veículo The Intercept Brasil, que vêm sendo veiculadas desde o dia 9 de junho de 2019. As reportagens revelaram conversas entre o então juiz federal Sérgio Moro e o chefe da força tarefa da operação Lava-Jato, o procurador Deltan Dallagnol. Pedro me recebeu na fila e fomos conversando enquanto aguardávamos. Já era a segunda pauta do dia do fotojornalista. A primeira, havia sido uma entrevista exclusiva com um senador no Congresso Nacional.

Fizemos nosso cadastro e passamos pelo detector de metais do prédio. Assim como Pedro, outros fotojornalistas estavam com diversos equipamentos fotográficos. Pedro estava com duas câmeras, sendo uma delas (a mais utilizada), equipada com uma grande lente teleobjetiva de $400 \mathrm{~mm}$, que pesa cerca de $3,5 \mathrm{~kg}$. Quase todos os outros fotojornalistas possuíam esse equipamento que permite fotografar de longa distância. Pedro saiu na minha frente e foi logo subindo pelo elevador. Eu fui depois e o encontrei já fotografando junto com outros fotojornalistas no fundo da sala, em espaço reservado aos cinegrafistas e fotógrafos. Pedro me explicou que a assessoria de imprensa do STF liberou acesso aos fotógrafos por 10 minutos depois de iniciada a sessão. A justificativa para esse limite de tempo é que o barulho dos cliques das máquinas fotográficas atrapalha os ministros e o transcurso da sessão. Pedro já sabia que o tempo que teria seria aproximadamente esse. Passados alguns instantes e muitas fotos de figuras ilustres da plateia como o advogado e ex-ministro da Justiça José Eduardo Cardozo, o advogado de Lula, Cristiano Zanin, e

10 É preciso destacar que o sujeito pesquisado autorizou, por escrito, a exposição do seu nome, o uso das notas de campo e das fotografias para fins de pesquisa acadêmica (Ver Apêndice 1). Foram anonimizados as pessoas com as quais ele interagiu no dia da observação. 
outros (Fotografia 1), Pedro se deslocou para um dos cantos da sala onde podia visualizar o espaço de bastidor, de onde sairiam os ministros.

Fotografia 1: Em primeiro plano, a senadora Gleisi Hoffmann e o advogado de Lula, Cristiano Zanin. Ao fundo o advogado e ex-ministro da Justiça José Eduardo Cardozo.

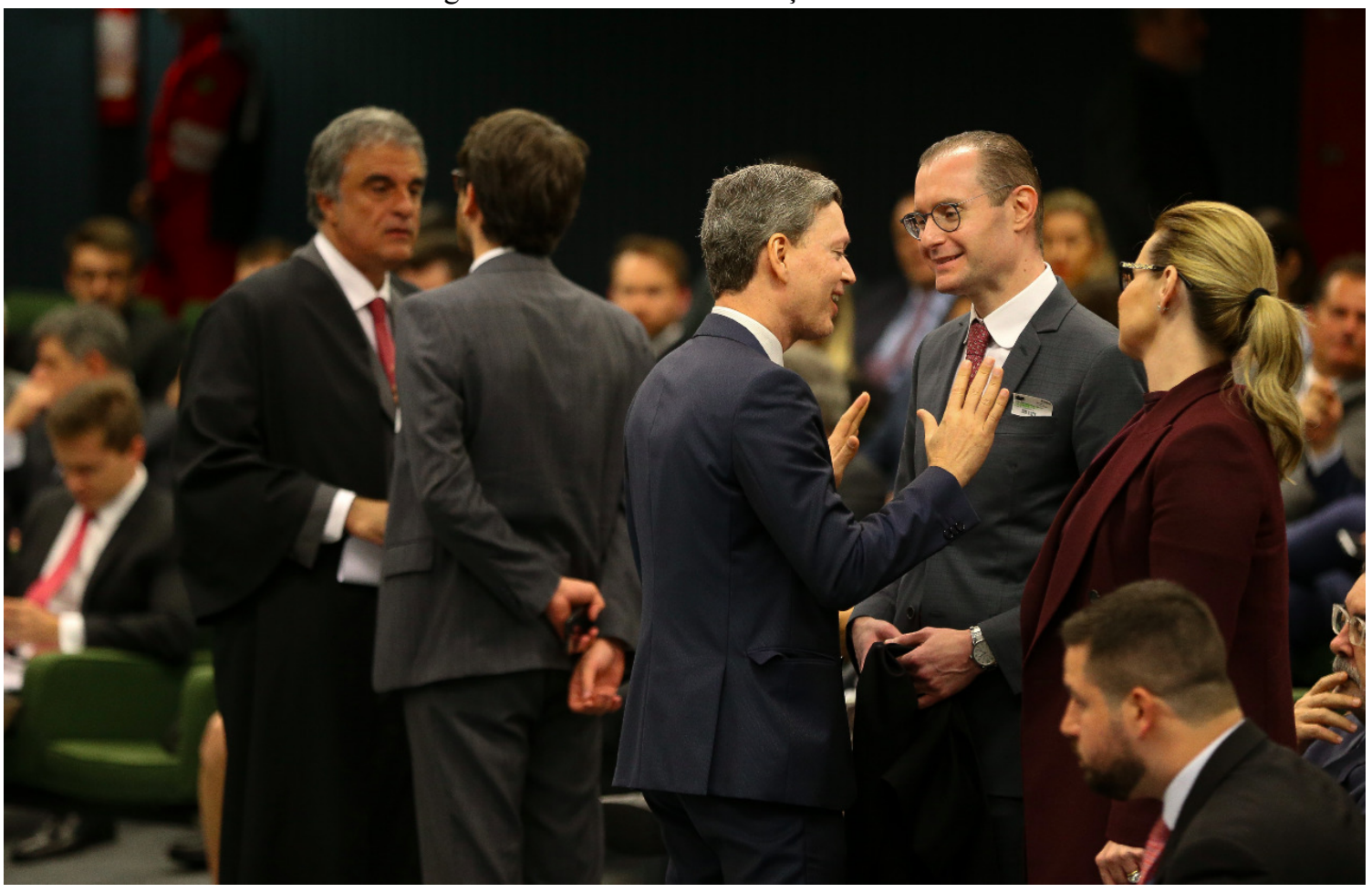

Foto: Pedro Ladeira - Folha de S. Paulo, 25/06/2019

Neste momento, enquanto esperava a saída dos ministros, Pedro me explicou o motivo de estar ali enquanto os demais fotógrafos estavam na posição inicial. Ele tentaria uma fotografia diferente dos demais. Uma foto de bastidor, talvez uma conversa entre os ministros ou um gesto enquanto se dirigiam à bancada. Segundo ele, era uma aposta. Podia render uma imagem interessante ou não. Pedro também me explicou que ele pertencia a uma nova geração de fotojornalistas, e como isso se relacionava com o fato de estar ali tentando produzir aquela imagem. Contou que há algum tempo os veículos exerciam muita pressão sobre os fotojornalistas para que eles apresentassem fotos de absolutamente tudo, 
de modo que a concorrência não possuísse imagens exclusivas de determinado evento. Para ele, hoje, ao menos no veículo em que trabalha, não há mais essa pressão. Pedro disse que a Folha incentiva que ele busque uma abordagem mais original, lhe permitindo explorar mais sua criatividade (Fotografia 2).

Fotografia 2: O ministro do Supremo Tribunal Federal Edson Fachin, momentos antes de entrar na sala de julgamento da $2^{\mathrm{a}}$ turma.

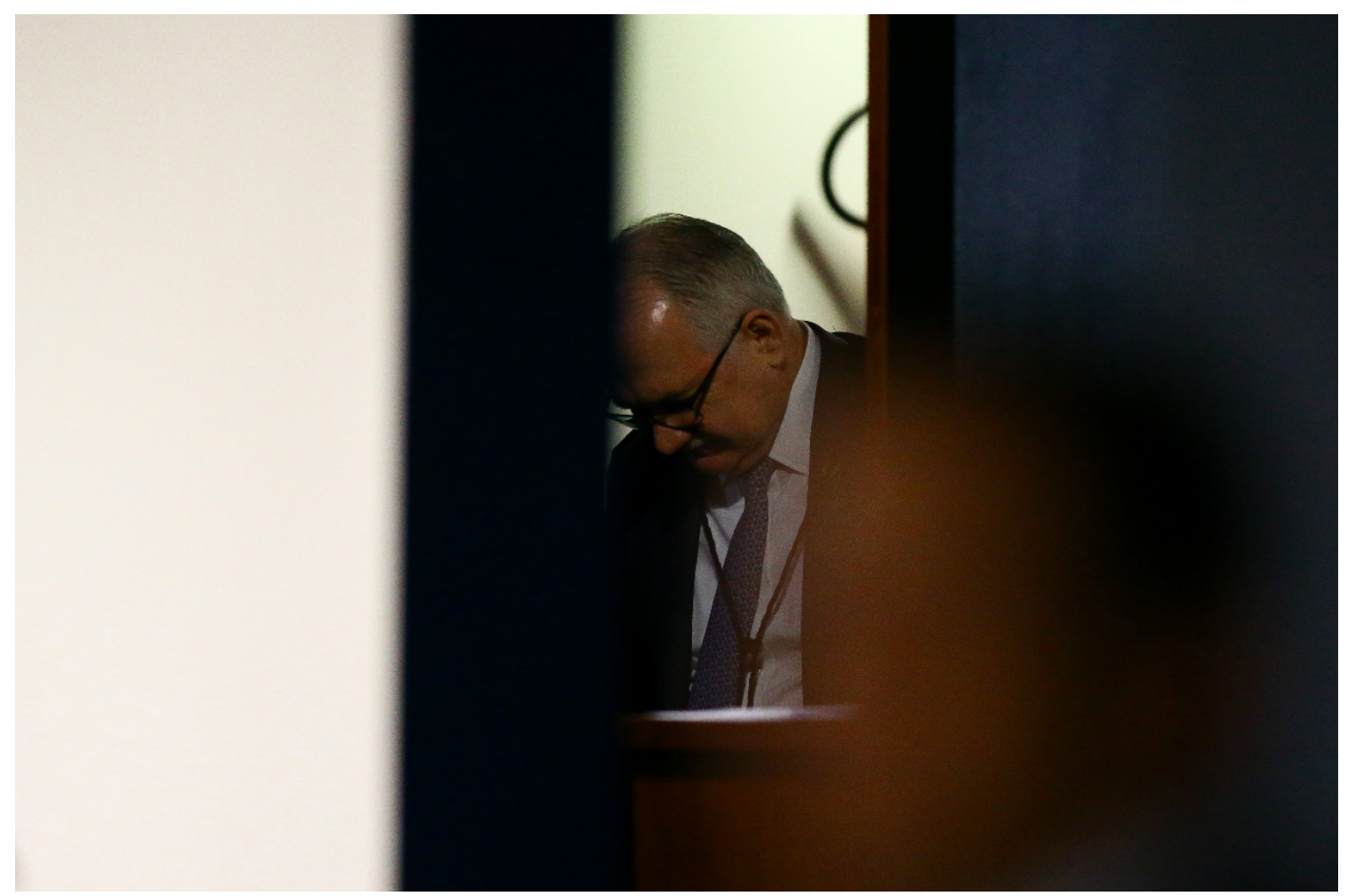

Foto: Pedro Ladeira - Folha de S. Paulo, 25/06/2019

Depois, conversamos um pouco sobre sua trajetória profissional. Ele trabalhou no Jornal de Brasília como estagiário entre 2007 e 2009 e como profissional contratado entre 2009 e 2011. Entre 2011 e 2013, foi freelancer e stringer (segundo Pedro, isso denomina uma espécie de funcionário coringa, um freelancer que é recorrentemente chamado) da agência internacional Agence France-Presse em Brasília. Entrou na Folha em 2013 com uma pequena equipe de fotojornalistas. Em 2017, começou a cobrir sozinho a pauta política de Brasília. Segundo ele, a redução da equipe deveu-se a situação econômica da empresa, que passou por reestruturações e cortes de pessoal nos últimos tempos. Em algumas situações, como em dias com muitas pautas, a Folha contrata freelancers para ajudá-lo ou 
mesmo para cobrir alguma folga que tenha direito. Pedro é um dos 3 fotojornalistas de todo o grupo Folha contratado via CLT, os demais são todos Pessoas Jurídicas ou freelancers. Por fim, ele me diz que devido ao corte de pessoal e por ser o único fotojornalista da Folha em Brasília, não há uma pressão para que ele consiga cobrir todas as pautas e, portanto, ter todas as imagens. Depois de tentar obter algumas fotos de bastidor, Pedro se desloca novamente para o centro da sala. Cristiano Zanin, advogado de Lula, começaria sua fala.

Pedro faz várias fotos de Zanin gesticulando, de costas e em primeiro plano, tendo Carmen Lúcia, presidente da segunda turma do STF, ao fundo (Fotografia 3). Ele já havia feito fotos dos ministros Gilmar Mendes, Edson Fachin e Celso de Mello. Pouco depois se esgotou o tempo determinado pela assessoria de imprensa do STF, e a equipe de seguranças começou a solicitar a saída de todos os fotógrafos. Pedro estava saindo quando visualizou Zanin entre os ministros Gilmar Mendes e Edson Fachin e lhe ocorreu fazer algumas últimas imagens com esse enquadramento (Fotografia 4). Apesar da solicitação para que saísse, Pedro parou, fez as fotos e pediu desculpasescusas à segurança.

Na saída, uma colega dele, jovem fotojornalista "Y" de outro veículo iniciou uma breve discussão com uma das seguranças que lhe abordou dizendo que estava se trajando de forma inadequada e apressando sua saída. Deixamos o prédio e nos encaminhamos, eu, Pedro, a fotojornalista Y e o experiente fotojornalista "Z", para a Câmara dos Deputados, onde a Comissão de Direitos Humanos ouvia o jornalista norte-americano Glenn Greenwald a respeito dos vazamentos e matérias publicadas pelo portal The Intercept Brasil. Seria a próxima pauta de Pedro e também de seus colegas. 
Fotografia 3: O advogado Cristiano Zanin em primeiro plano, a ministra Cármen Lúcia ao fundo.

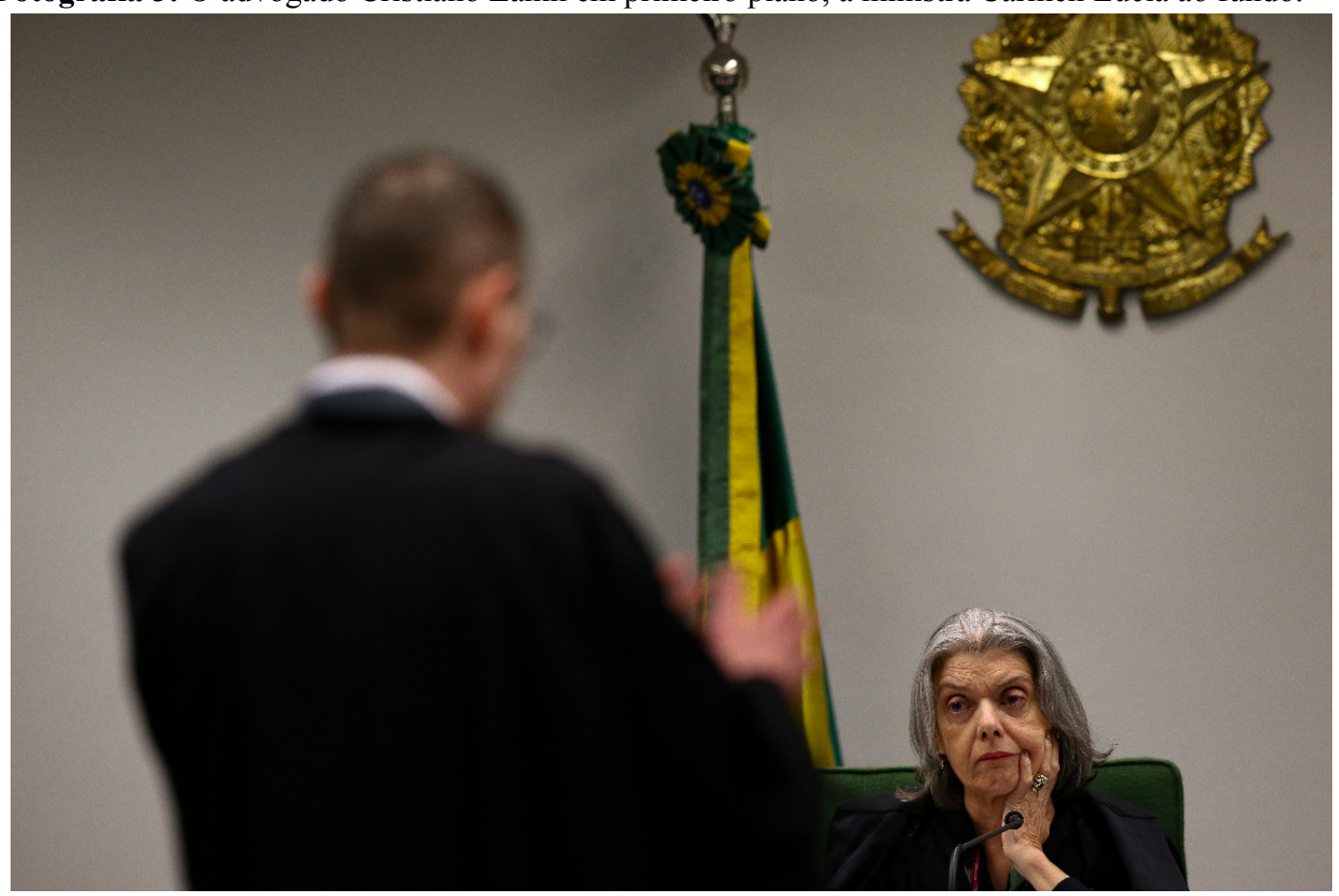

Foto: Pedro Ladeira - Folha de S. Paulo, 25/06/2019

Fotografia 4: O advogado Cristiano Zanin em primeiro plano entre os ministros 


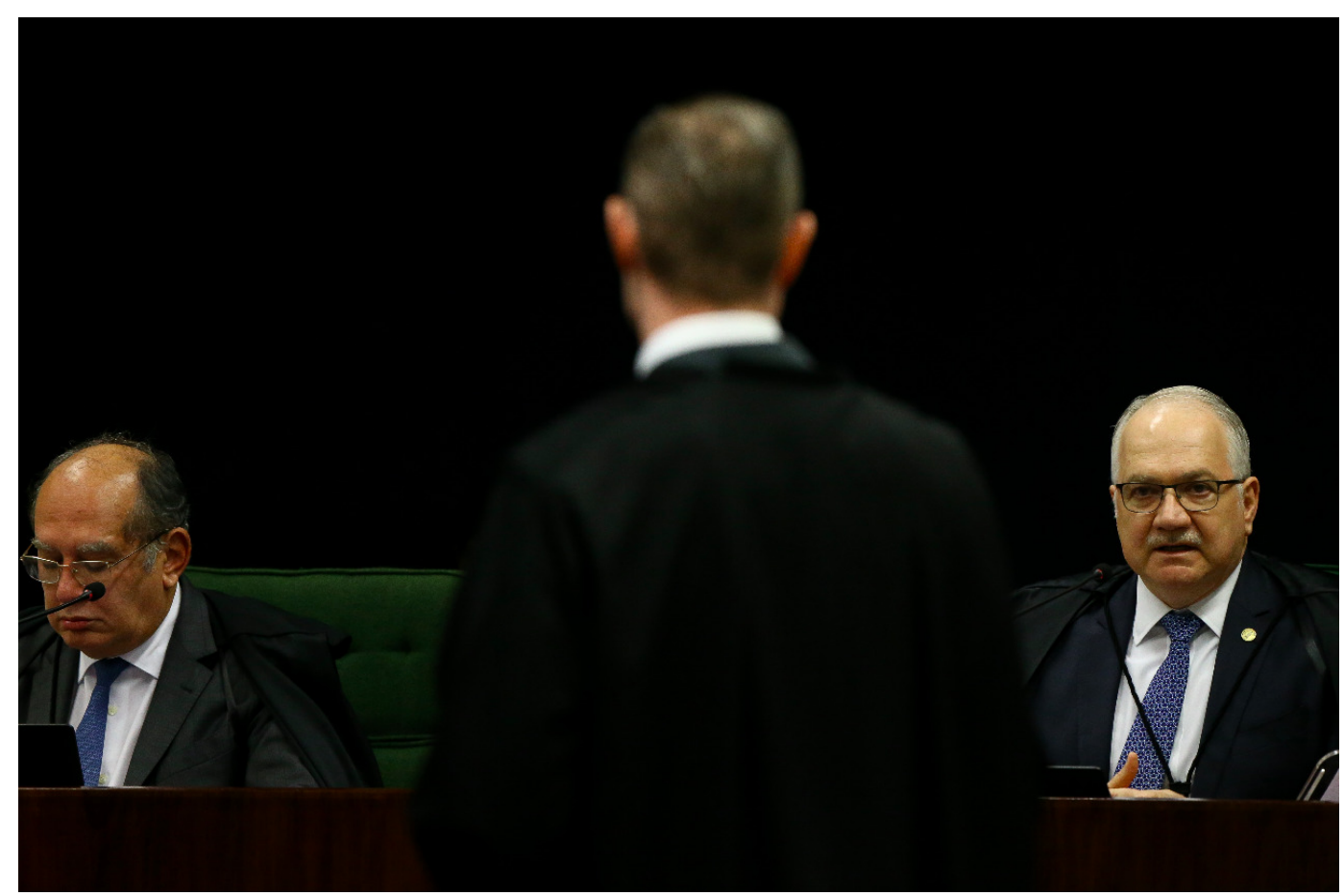

Gilmar Mendes (esq.) e Edson Fachin (dir.). Foto: Pedro Ladeira - Folha de S. Paulo, 25/06/2019

No caminho, os três fotojornalistas conversavam sobre o que havia ocorrido com a colega repreendida pela profissional de segurança. Em meio a conversa, Pedro me disse "em Brasília você passa o dia inteiro discutindo com segurança”. Mais tarde, me contaria sobre a importância em manter uma relação cordial com esses profissionais para conseguir realizar seu trabalho, a exemplo da forma como ele tratou a segurança quando parou para fazer suas últimas fotos no STF.

Antes de chegarmos à Câmara dos Deputados, Pedro recebeu uma notícia em seu celular dizendo que julgariam o pedido de soltura do ex-presidente Lula, algo que, até o início da sessão, era incerto. Em paralelo, avistamos a formação de uma aglomeração de apoiadores de Lula em frente ao STF, na praça dos Três Poderes. Pedro e Z resolveram ir até lá realizar algumas fotos. A fotojornalista Y decidiu cobrir o depoimento de Glenn. "O Glenn para mim é prioridade", disse ela. Chegando à manifestação, Pedro e Z conversaram sobre o fato de haver poucos público. Ao que Pedro disse: "manifestação se tem só um não é notícia". E Z: "vou fazer o bandeirão", ao avistar uma enorme bandeira com os dizeres "Lula Livre" estendida no chão. Depois de fazer a foto, $Z$ exclama: "Só para não dizer que 
eu não fiz!". Perguntei a Pedro se lhe agradava mais fazer fotos externas, de manifestações e eventos do gênero e se isso pesava na decisão de escolha de pauta. Ele me disse que há nas manifestações maior possibilidade de fotos bonitas, de sair do padrão, mas não chegou a afirmar que isso era algo primordial na escolha. Após mais algumas fotos partimos finalmente para a Câmara.

Ao chegarmos, Pedro foi direto à sessão da Comissão de Direitos Humanos, onde Glenn era sabatinado pelos deputados. Havia bastante tumulto e muita gente querendo entrar. Nem todos conseguiram, eu inclusive. Pedro entrou. Aguardei e poucos minutos depois Pedro estava de volta. Fomos juntos então ao comitê de imprensa, espaço reservado aos profissionais do jornalismo. Lá, Pedro realizou a seleção e o envio das imagens que havia feito até então. Pudemos conversar bastante nesse processo. Além desse trabalho de seleção, Pedro estava em constante contato com sua editora de imagens em São Paulo, por meio de mensagens no celular.

Durante a seleção das imagens conversamos sobre os critérios que ele utilizava. Pedro me disse que realiza as escolhas com base em suas informações do contexto. Ele explicou que escolhe com base nos personagens e nas tendências e que por isso precisa estar muito bem informado sobre o cotidiano político brasileiro. "Não fiz foto do Lewandowski porque sei que ele não é importante”, disse. "O Zanin já é notícia! É o advogado do Lula", justificando a escolha de várias fotos em que o advogado interage com Carmen Lúcia. "Essa aqui é legal, o Zanin entre o Gilmar e o Fachin (Fotografia 4), essa aqui eu consegui no final pela complacência da segurança, então a gente precisa ter uma boa relação com eles", revela. Mais tarde, Pedro relatou outra situação envolvendo sua relação com seguranças. Disse ainda que, cobrindo agenda presidencial, já precisou de certa maleabilidade no trato com os seguranças do presidente, especialmente quando Bolsonaro faz algo inusitado como parar o veículo oficial para cumprimentar ou tirar foto com alguém, "fazer embaixadinha". Nesses momentos precisa que os seguranças o deixem se aproximar para fazer as fotos. Ele explicou ainda que os seguranças sabem que também é bom para a imagem do presidente esse tipo de foto e que talvez por isso permitam essa aproximação.

Pedro me mostra em seu celular um trecho da conversa com a editora. Na mensagem, ele explica que fez algumas fotos de dentro da sessão na segunda turma do STF. “Tá vendo, 
aqui você vai vendendo o peixe", me diz. Em outra mensagem ele recebe uma pauta para o dia seguinte pela manhã ao que ele responde solicitando para não fazê-la devido a um compromisso pessoal. O fotojornalista então fica aliviado com a resposta positiva da editora. Ao final do processo, ele seleciona 17 das 830 fotos que fez. Então, ele começa o trabalho de legendar cada uma das imagens selecionadas. Pergunto se haverá alguma revisão do seu trabalho, ele diz que apenas para as publicações principais diárias do grupo Folha, nas demais publicações e empresas do grupo as pessoas autorizadas apenas acessam e pegam as imagens direto de um banco de dados. Pergunto se ele cumpria, então, um papel de editor local de imagens. Ele disse que sim, já que tinha muita liberdade para fazer seu trabalho. Pedro também contou sobre um equipamento que envia as fotos tiradas diretamente da câmera fotográfica para o banco de dados. Ele disse que usou durante um tempo o equipamento, mas que parou, pois apesar da maior agilidade no envio das fotos, o processo como um todo perdia qualidade, além das imagens não passarem por uma préseleção, nem uma legendagem.

Em nova troca de mensagens, Pedro e sua editora conversam sobre qual pauta deve fazer a partir daquele momento. A editora tem bastante interesse na manifestação pró-Lula, diz que será a foto de capa do dia seguinte e pede para Pedro se concentrar nisso. Pedro concorda, diz que vai esperar a manifestação crescer mais e que voltará lá em breve. Passado algum tempo, por volta das 17h, retornamos à Praça dos Três Poderes onde, de fato, a manifestação estava maior do que antes. Reencontramos Z e Y. Pedro decidiu fazer mais algumas fotos, tendo em vista que a luz estava diminuindo em virtude do fim do dia (Fotografia 5). Após fazer as imagens ele volta a conversar com sua editora, por volta das 17h30. Pedro diz que a manifestação está rendendo pouco, pois não havia tantas pessoas e as que havia estavam dispersas. Ele pergunta se já deveria mandar as fotos que tinha, ao que a editora responde positivamente já que se aproximava do segundo horário de reunião de fechamento do jornal, às $18 \mathrm{~h}$.

Fotografia 5: Apoiadores do ex-presidente Lula se manifestando em frente à Praça dos Três Poderes. 


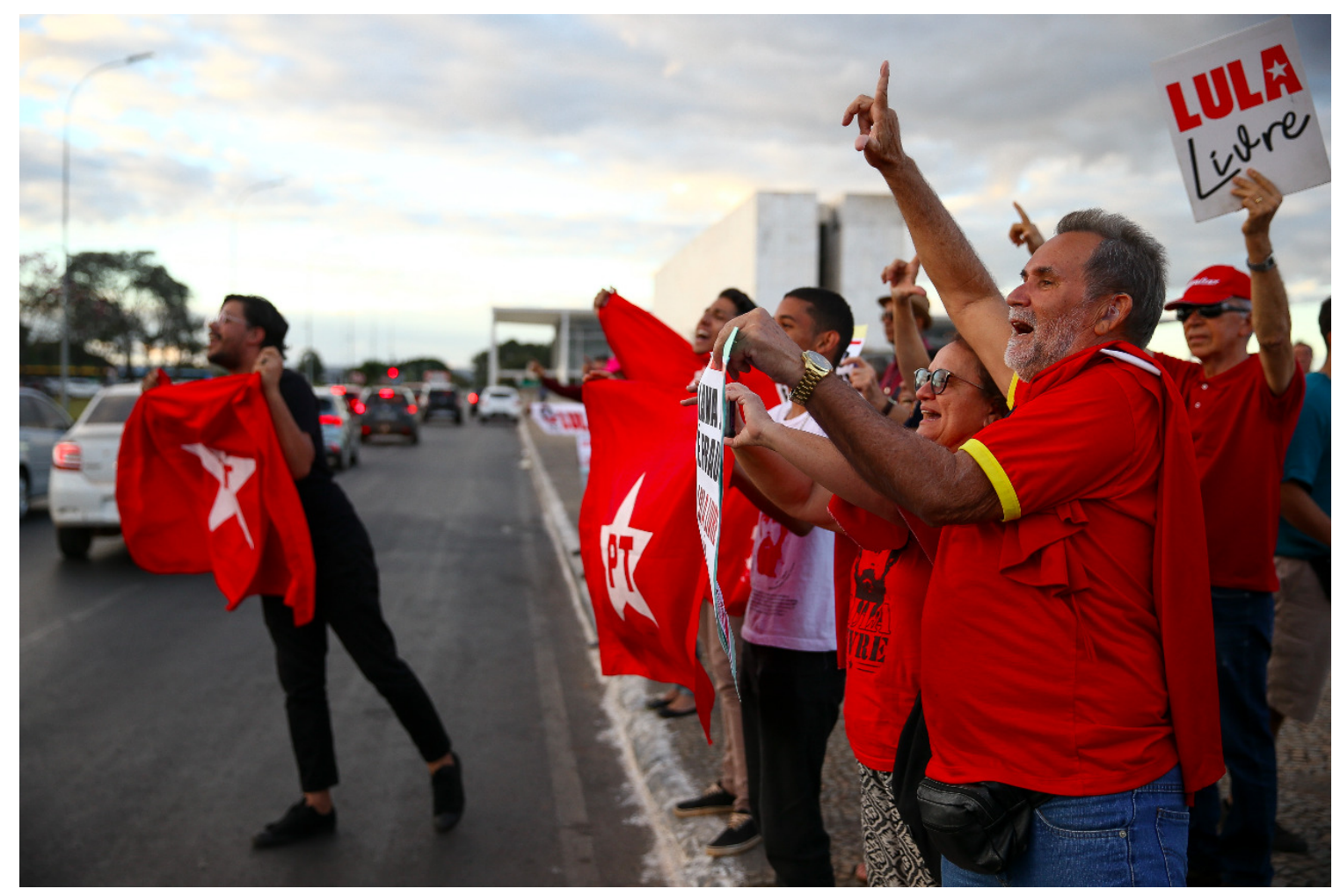

Foto: Pedro Ladeira - Folha de S. Paulo, 25/06/2019

Pedro então se senta no meio fio junto com alguns outros colegas de diversos veículos, inclusive $\mathrm{Z}$ e Y, liga seu notebook e começa a fazer nova seleção de fotos. $\mathrm{O}$ fotojornalista não quer sair dali pois poderia acontecer alguma coisa que valesse a pena ser registrada. Enquanto realizava seu trabalho conversamos sobre o fluxo da Folha de $S$. Paulo. Ele me diz que embora mantenha mais contato com os editores de imagem de São Paulo, a pauta diária é feita de manhã pela equipe da sucursal de Brasília (composta por 18 repórteres e dois chefes de redação). Essa equipe envia uma pauta para os profissionais de Brasília e de São Paulo. Contudo, Pedro me diz que essa pauta geral não define sua diretriz de trabalho. Ele a recebe e avalia se a segue ou não, sempre conversando com os editores de imagem de São Paulo. Pedro me diz que muita coisa ele decide sozinho. Também me explicou que em São Paulo acontecem diversas reuniões ao longo do dia, sendo algumas mais importantes para seu trabalho, como a das 9h, que define as prioridades; e a das 16h, que é a primeira reunião para definição da capa do jornal. Nesses horários ele precisa estar atento ao celular. Em seguida, reconhece que está em posição privilegiada na Folha, pois o jornal confia em seu juízo e lhe dá autonomia para escolher, em muitas ocasiões, o que 
cobrir. Pedro acredita que isso varia muito de jornal para jornal. Há aqueles, como o veículo da colega $Y$, em que o editor gosta de mandar no fotojornalista. Pedro também comentou o que ele chamou de situação "potencialmente perigosa", quando o editor diz ao fotojornalista "Avalia aí!". Segundo ele, em alguns casos esse tipo de liberdade pode trazer algum revés ao fotojornalista quando, no outro dia, a aposta em determinada pauta mostrarse equivocada por não ter repercutido tanto, ao que ele conclui que o grande desafio é justamente a avaliação do que é notícia.

Perguntei também sobre a estrutura de trabalho. Ele me disse que todo o equipamento fotográfico é da Folha. Disse também que, como a empresa não dispõe de motoristas, ele se locomove usando o aplicativo Uber por meio de uma conta empresarial. Segundo ele, essa dependência de transporte via aplicativos dificulta a cobertura de algumas pautas, como quando precisa, por exemplo, seguir uma comitiva presidencial. Por conta disso, geralmente trabalha cobrindo o Planalto, Congresso Nacional e STF, todos na Praça dos Três Poderes, em Brasília. Em seu celular ele possui um aplicativo que conta passos e me disse que normalmente percorre de 6 a $8 \mathrm{~km}$ a pé por dia apenas nesse espaço.

Pedro então conversa com os demais colegas sobre a forma como cada veículo vai noticiar a manifestação. Segundo Y, seu veículo certamente vai noticiar de forma pejorativa. Ela reafirma que aquele evento não interessa muito aos editores. Estávamos acompanhando a votação pelas reações do grupo de manifestantes quando finalmente chegou a notícia de que Lula não seria solto. Um grupo pequeno de apoiadores do presidente Jair Bolsonaro e do ministro da Justiça Sérgio Moro, que se formara do outro lado da rua, começa a festejar a decisão. Os fotojornalistas imediatamente começam a fotografá-los, incluindo Pedro, que envia as novas fotos ao jornal (Fotografia 6). 


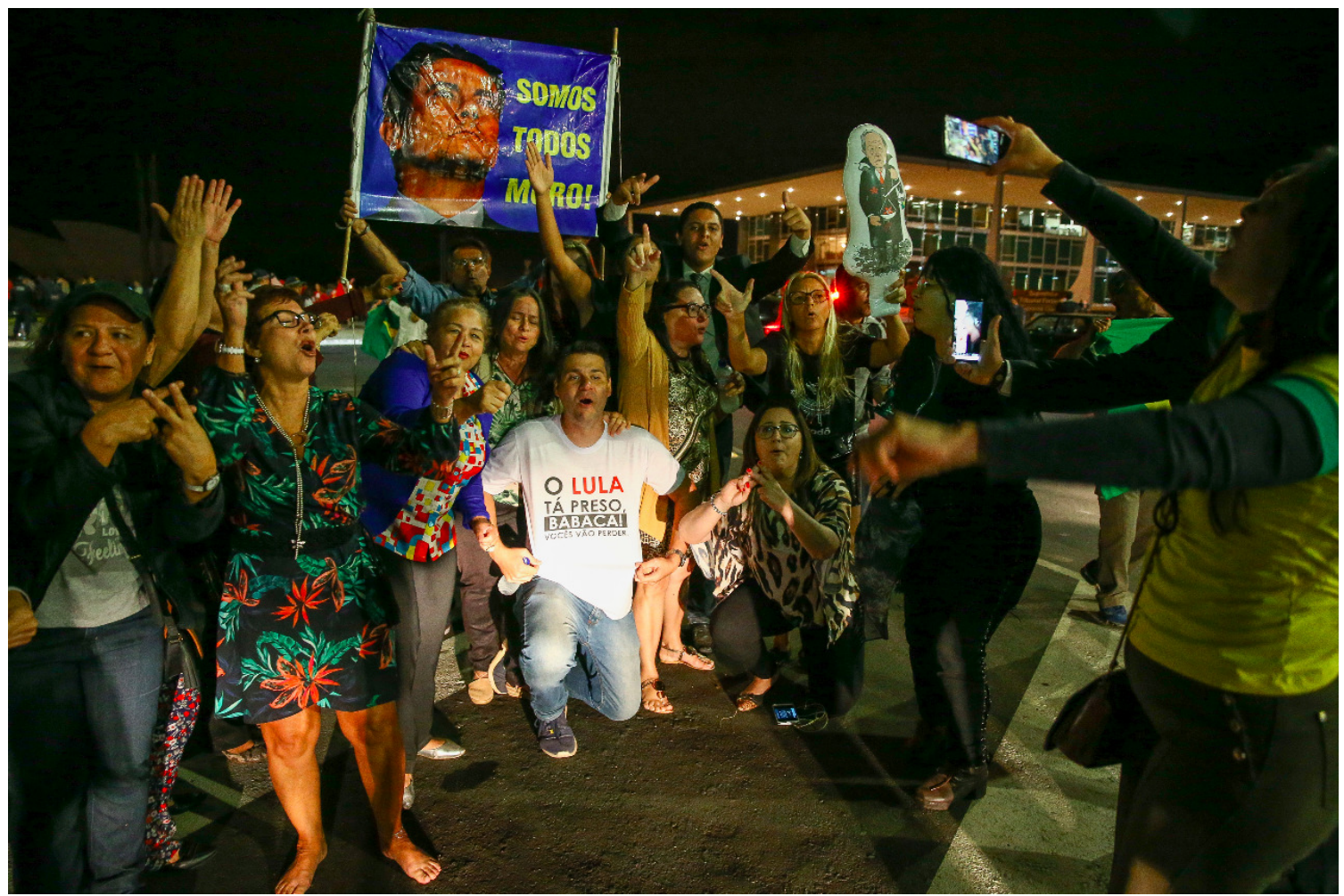

Fotografia 6: Manifestantes pró-Governo comemoram a manutenção da prisão de Lula. Foto: Pedro Ladeira - Folha de S. Paulo, 26/06/2019

Após o envio deste material, estava terminado o dia de trabalho de Pedro. Agradeci a disponibilidade em participar da observação e nos despedimos.

\section{Análise de dados}

Os dados trazidos pela observação de um dia de trabalho do fotojornalista Pedro Ladeira, da Folha de S. Paulo, revelam um pouco da complexidade das várias arenas na qual um fotojornalista atua e como esse profissional integra o mundo social dos jornalistas. O fotojornalista revelou-se de fundamental importância para esse mundo social, integrando as rotinas da produção da informação. Destacaremos em nossa análise alguns pontos que reforçam esse argumento com base na perspectiva dos mundos sociais. Concentramos nossa abordagem em três eixos: 1. Sua participação na rede de cooperações do mundo dos jornalistas; 2. Sua capacidade de se apropriar e renegociar aspectos do sistema de convenções desse mundo social; 3. Sua relevância nessa prática coletiva como uma forma 
de questionar o senso comum, que situa esse ator muitas vezes como uma pessoa de menor importância no ato social da produção de notícias, apesar das mudanças no estatuto da imagem fotográfica na comunicação social.

Se um mundo social pressupõe "uma rede de pessoas envolvidas na realização de uma atividade cooperativa" (Becker, 1982) a fim de realizar "um ato social maior" (Strauss, 1978), é preciso que se entenda como se dão as relações, negociações e conflitos entre essa rede de atores. Nesse sentido, a descrição realizada a partir de nossa observação e conversa com nosso objeto, além das fotografias cedidas pelo informante, permite-nos rascunhar o desenho dessas arenas, ou dos "lugares de confronto e cooperação entre os mundos sociais" (Flichy, 1995:15). Os atores observados foram o próprio fotojornalista Pedro Ladeira, sua editora de imagens em São Paulo, seus colegas de ofício (repórteres, cinegrafistas e especialmente outros fotojornalistas), as fontes fotografadas, os seguranças e pessoal de controle e regulação de acesso aos espaços que percorremos. De forma menos explícita, Pedro também interage, em seu cotidiano, com os motoristas de Uber e com o próprio aplicativo quando precisa se locomover fora do espaço da Praça dos Três Poderes.

Dessa forma, chamamos a atenção para a importância dos profissionais de segurança na imposição de limites ao trabalho dos fotojornalistas. O exemplo do ocorrido dentro do plenário da segunda turma do STF - quando Pedro conseguiu suas últimas imagens mesmo após a equipe de seguranças retirar os fotojornalistas do local - mostra como uma boa relação com estes profissionais muitas vezes garante ou facilita a realização do trabalho. Assim, Pedro reconhece a necessidade de manter uma relação cordial com esses atores. Como ele mesmo disse: "Em Brasília, você passa o dia inteiro discutindo com segurança". De fato, observamos que Pedro é um sujeito bastante simpático e notadamente já conhecido nos bastidores do poder da Capital Federal. Ao contrário, a colega Y, com um mês apenas de atuação na cidade, provavelmente não se deu conta ainda da importância da manutenção dessas relações e talvez por isso tenha entrado em uma discussão com a segurança do STF. A importância da relação com esses profissionais, aliás, fica bastante óbvia quando verificamos que foi justamente essa fotografia (Fotografia 4) a escolhida como capa do jornal do dia seguinte (26/06/2019) pelos editores da Folha (imagem 1).

Imagem 1: capa do jornal Folha de S. Paulo do dia 26/06/2019 


\section{FOLHA DE S.PAULO}

DESDE $1921 \star \star \star$ UM JORNAL A SERVIÇO DO BRASIL

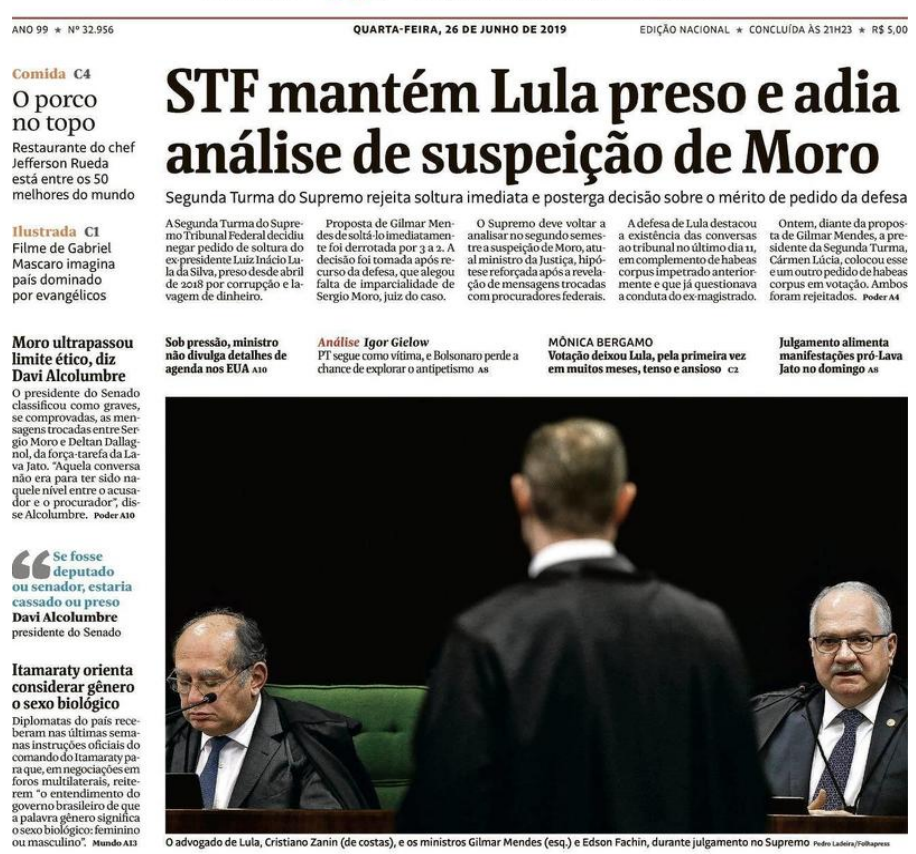

Elio Gaspari

Rio nảo preciso

do autódromo

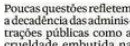

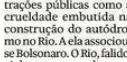

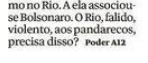

Mentor da F-1 no
Rio deve à União Rio deve à União
R\$ 24,7 milhões

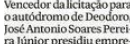

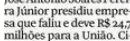

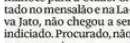

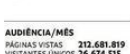

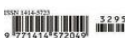

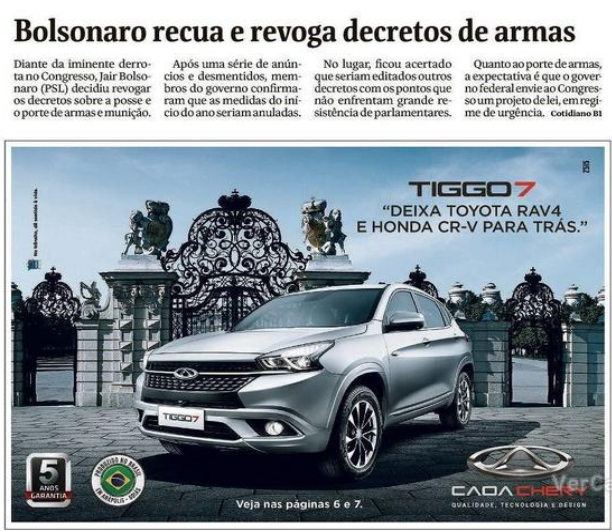

Petrobras negocia com Cade abertura Estatal negocia a ve
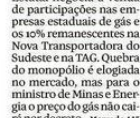

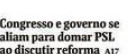

Camara do Rio rejeita
pedido de impeachment

Casal é suspeito de
manter idosa em cárcer
privado por 20 anos 81

EDITORIAIS A2

O caso Lula
Sobre decisáo do STF de

Fonte: Folha de S. Paulo ${ }^{11}$

Outro momento em que percebemos a importância desses profissionais foi no acesso de Pedro à Comissão de Direitos Humanos, onde depunha o jornalista Glenn Greenwald. Apesar da enorme aglomeração e da evidente lotação do espaço, Pedro conseguiu entrar sem maiores dificuldades, passando na frente de outras pessoas, possivelmente por já conhecer o segurança do momento. O papel desempenhado pelos seguranças na regulação do acesso aos locais de cobertura ilustra ainda a necessidade de ampliarmos a própria noção

11 Disponível em <https://www.vercapas.com.br/capa/folha-de-s-paulo/2019-06-26.html>. Acessado em $21 / 11 / 2019$ 
de sistema de convenções que, no caso do fotojonalismo, vai além dos conhecimentos técnicos e estéticos em fotografia ou o domínio dos valores-notícia. Passa também pela capacidade de negociação com esses atores. Desconhecer essas convenções, como mostra o caso da jornalista Y, não inviabiliza a prática do fotojornalismo, mas afeta o resultado final do trabalho - algo parecido foi descrito por Becker (1982) em sua análise sobre o mundo das artes.

Com relação a editora de imagens do grupo Folha de S. Paulo não há uma imposição hierárquica, como poderia parecer a princípio. As trocas de mensagens entre ambos, no momento em que estávamos no comitê de imprensa, mostram uma relação aparentemente mais horizontalizada do que poderíamos imaginar, especialmente no que diz respeito à escolha editorial. Quando Pedro me diz "Tá vendo, aqui você vai vendendo o peixe", ele faz referência às negociações que dizem respeito ao produto final. Nesse sentido, aceitar ou não as fotografias propostas por Pedro envolve uma série de avaliações feitas pela editora com base não só no produto final (e a forma como ela atribui ou não valor estético e jornalístico às imagens), mas também na reputação do fotojornalista. Também demonstra a confiança no trabalho de Pedro uma vez que há a necessidade da editora de tomar uma decisão rápida e eficaz em função dos constrangimentos impostos pela produção do jornal.

Essas situações nos levam naturalmente a discutir o papel dos sistemas de convenções na regulação das relações dessa rede complexa com os atores que integram o mundo social do qual Pedro faz parte. Por um lado, esse sistema de convenções estabelece as bases da cooperação, facilitando a prática coletiva. Por outro, impõem limites à autonomia dos profissionais em propor inovações, justamente porque uma inovação muito radical geralmente exige mais tempo e energia, além de envolver sempre o risco de fracasso. Tal situação foi comentada por Becker ao falar do mundo das artes:

Ao acomodar suas concepções a recursos disponíveis, os artistas convencionais aceitam as restrições decorrentes da dependência da cooperação dos membros do mundo da arte existente. Em qualquer momento, o artista depende de outros para algum componente necessário, ele deve aceitar as restrições que imporem ou 
gastar o tempo e a energia necessários para proporcionar-lhe de outra forma. (Becker, 1974a: 770) ${ }^{12}$

Fazer de outra maneira algo que é convencionado de determinada forma exige, portanto, um investimento maior em tempo e energia. Nesse sentido, é interessante observarmos a estratégia de Pedro Ladeira e suas falas no momento em que tenta conseguir uma foto dos bastidores da entrada dos ministros do STF (Fotografia 2). Segundo Ladeira, se deslocar para aquela posição era uma aposta em tentar uma abordagem original da entrada dos ministros, atitude que era, segundo o próprio, estimulado pela Folha. Por um lado, essa postura procura uma inovação estética no mundo dos jornalistas, na maneira em que ela se difere do que é convencionalmente feito pelos fotojornalistas que cobrem política.

Em geral, há na cobertura fotográfica de Política uma prática comum de realizar uma infinidade de cliques, em geral do rosto dos personagens, a fim de se conseguir algum instantâneo que capture uma expressão desejada pela linha editorial do veículo de comunicação. De fato, a metralhadora de cliques 13 das câmeras ao fundo da sala do STF revela que a maioria dos profissionais estavam seguindo esse procedimento. A atitude de Pedro, de se deslocar desse grupo e buscar uma imagem diversa revela, ainda que de forma preliminar, um movimento mais amplo de reorganização das relações entre alguns atores. É o que próprio fotógrafo explica, ao falar sobre a diferença de uma nova geração de fotojornalistas, da qual ele faz parte, com relação a uma geração anterior, em que havia, segundo ele, maior pressão para a produção de fotos do maior número de situações possíveis, em detrimento da qualidade ou de um olhar mais estético, que demandaria mais tempo e trabalho para a produção.

É interessante verificar como essa pequena inovação convencional, em particular no caso da Folha de S. Paulo, se relaciona ao contexto maior de mudanças que explicitamos no início deste trabalho e que exigiu, desde 2017, a demissão dos demais

12 Do inglês original: "By accommodating their conceptions to available resources, conventional artists accept the constraints arising from their dependence on the cooperation of members of the existing art world. Wherever the artist depends on others for some necessary component he must either accept the constraints they impose or expend the time and energy necessary to provide it some other way." Tradução dos autores.

13 Com a evolução técnica das câmeras fotográficas, a chamada velocidade de obturação (tempo da exposição fotográfica medido em frações de segundo) aumentou sobremaneira. Hoje, os fotojornalistas trabalham com câmeras que conseguem realizar até 14 fotografias por segundo, de modo que tais imagens oferecem todo um cardápio de expressões que podem ser utilizadas pelos veículos de comunicação. 
fotojornalistas que cobriam Brasília, do motorista, entre outros eventuais atores que interferem no trabalho de Pedro. Aparentemente, a resposta da Folha à atual conjuntura de escassez de recursos tem sido o estímulo à inovação de seus empregados.

Nossa leitura dos dados mostra que Pedro domina as convenções já estabelecidas do fotojornalismo da Folha de S. Paulo, o que orienta suas interações com seus colegas e leitores, especialmente sobre os valores-notícia que regem a editoria da empresa. De fato, tanto a observação de campo quanto a análise das fotografias mostram que ele também produziu fotos mais convencionais e semelhantes àquelas tiradas pelos demais fotojornalistas envolvidos na cobertura. Como já explicamos, a adoção de práticas convencionais deixa mais eficaz o trabalho de colaboração, em situações, por exemplo, de falta de tempo. É o que aconteceu quando Pedro foi cobrir a sabatina do jornalista Glenn Greenwald na Comissão de Direitos Humanos. Provavelmente isso se relacione com o fato de que, embora soubesse da preferência convencional da Folha e de seus leitores pela manifestação pró-Lula, poderia, caso permanecesse todo o tempo dedicado a manifestação e deixasse de fazer as fotos de Glenn, ser cobrado por uma escolha equivocada. Como revelou mais tarde - quando se referia aos casos em que o editor diz "avalia aí" para o fotojornalista.

Ou seja, ao mesmo tempo em que a inovação através de um investimento em uma foto não convencional parece ter se tornado a nova convenção na Folha de S. Paulo, a velha convenção de ter fotos de diversos eventos parece estar ainda, em alguma medida, em vigor. Embora o grande conhecimento de Pedro sobre os valores-notícia da empresa e a liberdade que lhe é conferida para decidir o que e como cobrir um assunto o autorizem, em tese, a tomar decisões importantes, seu instinto de sobrevivência lhe orienta a não exagerar em suas tentativas de inovação, especialmente no que se refere aos limites dessas escolhas. Foi o que ocorreu com a cobertura do depoimento de Glenn Greenwald. Pedro sabia que embora esse não fosse o foco principal da Folha no momento, a falta dessa foto poderia lhe ser eventualmente cobrada no futuro. De fato, a foto de Glenn, bastante simples do ponto de vista formal e narrativo, acabou sendo utilizada na publicação de uma rede social da Folha: 
Imagem 2: Publicação na mídia social Instagram da Folha de S. Paulo no dia 25/06/2019
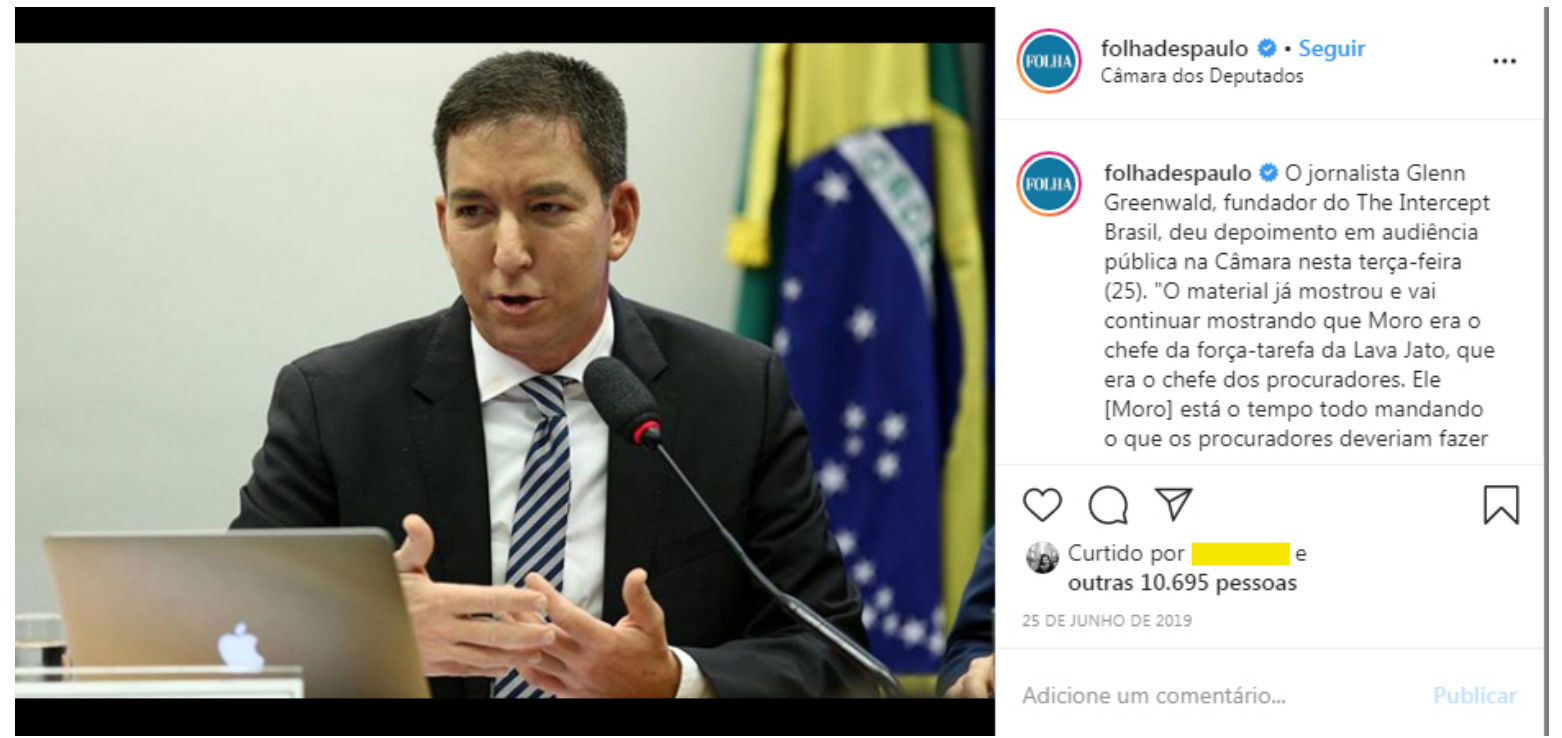

Foto: Pedro Ladeira - Folha de S. Paulo, 25/06/2019

Ao dominar o sistema de convenção, o fotojornalista também se antecipa às expectavas de outros atores que colaboram com o mundo social. Dependendo do seu conhecimento sobre esse sistema de convenções, permite que ele inclusive, renegocie o seu status no interior desta prática. Nesse sentido, a distinção proposta por Becker (1974a; 1982) entre os atores que desempenham as atividades centrais de mundo (core activiy) e pessoal de reforço é algo movediço, constantemente renegociado. Mesmo que o senso comum costume situar o repórter como o ator que produz a notícia, colocando o fotojornalista como o produtor de uma informação suplementar, auxiliar, nossa observação mostra que: 1. Os fotojornalistas também dominam o sistema de seleção dos fatos a serem noticiados, o que os teóricos do jornalismo chamam de critérios de noticiabilidade (Silva, 2005); e 2. Dependendo do contexto, eles podem se tornar atores centrais no processo de construção do noticiário, como parece ser o caso de Pedro Ladeira na atual configuração de trabalho da Folha de S. Paulo ${ }^{14}$.

14 Alguns cliques de Pedro Ladeira já lhe fizeram, inclusive, assumir as funções de fotografo e também de jornalista se tornando de fato uma figura central no ato social da produção de notícias da Folha. Tratamse de dois flagrantes de mensagens de celular de personalidades políticas em que a foto e o texto foram feitos por ele: "Ministros do PMDB não deixarão cargo, diz Kátia Abreu em mensagem", disponível em: https://www1.folha.uol.com.br/poder/2016/03/1755611-ministros-do-pmdb-nao-deixarao-cargo-diz-katia- 
Assim, o momento em que estávamos caminhando do STF rumo à Câmara dos Deputados é revelador das competências dos fotojornalistas em relação ao seu nível de conhecimento sobre os valores-notícia de cada empresa de comunicação. Ao avistarmos o início da manifestação, os três fotojornalistas rapidamente decidiram o que fazer. Y descartou logo a cobertura da manifestação, enquanto Pedro e $\mathrm{Z}$ imediatamente decidiram adiar a ida ao Congresso para ficar ali um pouco e fazer fotos. Para Y e seu jornal, era importante dedicar mais tempo à cobertura de Glenn, pois para sua linha editorial (que não deixa de fazer parte de um sistema de convenções ${ }^{15}$ ) provavelmente uma maior quantidade de imagens e logo de expressões e gestos de Glenn seria importante. Ao passo que para a Folha de S. Paulo e o veículo de Z era a manifestação a favor de Lula o evento de maior relevância. No momento da edição das imagens, da mesma forma, é o conhecimento das convenções que torna o trabalho de Pedro muito ágil naquele momento. É a familiaridade com esse sistema que lhe permite tomar decisões rápidas como não tirar fotos do ministro Ricardo Lewandowski, por exemplo, ou escolher as imagens do advogado Cristiano Zanin interagindo com a ministra Carmen Lúcia.

Outro ponto observado que revela como a noção de valor notícia é compartilhada pelos diversos atores de uma arena, como afirma Pereira (2018), é o caso narrado por Pedro sobre as eventuais fotos do presidente Jair Bolsonaro em momentos descontraídos, onde seus seguranças aquiescem que os fotógrafos se aproximem. Nesse caso, o valor notícia de uma imagem de descontração e popularidade do presidente é conhecida não apenas pelo fotojornalista, mas também pelos seguranças e, por que não dizer, pelo próprio presidente da República. Nessa arena de negociação, poderíamos pensar na fotografia produzida e numa eventual futura matéria, como um ato social coletivo construído não apenas pela equipe de jornalismo, mas também pelo segurança e mesmo pelo presidente da República.

abreu-em-mensagem.shtml, Acessado em 14/02/2020 ; "Em mensagem, Moraes diz que Temer vai anunciá-lo às 19h ao STF", disponível em: https://www1.folha.uol.com.br/poder/2017/02/1856259-emmensagem-moraes-diz-que-temer-vai-anuncia-lo-as-19h-ao-stf.shtml, acessado em 14/02/2020.

15 Sobre essa questão e o modo como um sistema de convenções (como é o caso das linhas editoriais dos veículos de comunicação) se relaciona a um sistema representativo Becker diz que "Representar a realidade (...) consiste geralmente no fato de uma comunidade interpretativa, um conjunto organizado de indivíduos (os 'fabricantes') produzirem de maneira regular um conjunto de representações estandardizadas de um tipo particular, destinada a outras pessoas (os 'usuários') que se servem dessas representações de forma corrente e para objetivos estandardizados" (Becker, 2009: 22). 
Outro momento interessante da observação diz respeito à fala de Pedro sobre a tentativa de implementação do equipamento que envia as fotos diretamente da câmera para a base de dados da Folha. Segundo ele, essa tentativa de inovar acabou se mostrando ineficaz e deixou de ser adotada em sua rotina. Do lado do fotojornalista, podemos pensar que, ao não demandar sua edição, o processo comprometia seu controle estético sobre o material. Do lado do editor, o aumento de seu fluxo de trabalho com seleção e tratamento de imagens representou uma sobrecarga desnecessária e improdutiva. Como diz Becker: “Convenções representam o ajustamento contínuo das partes cooperadoras para a mudança das condições nas quais eles praticam, quando as condições mudam, eles mudam ${ }^{16 " ~(1982: ~}$ 59). Contudo, há que haver um acordo para que haja o estabelecimento de nova convenção. Se para os donos da Folha o equipamento permitiria alguma economia de recursos e de tempo, para os demais não houve, obviamente, nenhum ganho que os fizesse aceitar essa mudança, de modo que o equipamento caiu em desuso.

\section{Conclusão}

Neste trabalho, observamos o cotidiano de um fotojornalista em Brasília com o objetivo de compreender sua inserção na produção jornalística, vista como uma atividade coletiva e cooperativa. A partir da perspectiva dos Mundos Sociais, de H. S. Becker (1974a; 1982), voltamos nossa atenção não só para o trabalho fotojornalístico, mas para as formas convencionais de cooperação de atores normalmente invisibilizados, mas que participam deste ato social. A partir de uma abordagem etnográfica, tivemos condições de analisar a especificidade e complexidade da arena de atuação do fotojornalista e a forma como seu trabalho participa da criação e da atualização das convenções que existem neste mundo social.

Além dos resultados da pesquisa e de seus aportes teóricos, destacamos como uma das grandes contribuições deste trabalho a adoção de uma metodologia mista, que combina uma observação de campo com um trabalho de sociologia visual, em que analisamos parte

16 Do inglês original: "Conventions represent the continuing adjustment of the cooperating parties to the changing conditions in which they practice, as conditions changes, they change". Tradução dos autores. 
do que foi produzido pelo informante desta pesquisa. Apesar das limitações em termos de exaustividade dos dados gerados, acreditamos que o procedimento metodológico adotado poderia ser replicado para outras análises de atores do mundo dos jornalistas, bem como de outras práticas de representação da sociedade (Becker, 2009).

Evidentemente que nosso trabalho não esgota a enorme quantidade de mudanças nas formas de fazer e nas convenções do mundo social dos fotojornalistas atualmente. Nosso objetivo foi verificar questões pontuais que parecem indicar um aumento da relevância dos profissionais da fotografia nesse contexto. Nesse sentido, é importante observarmos como, por uma série de questões (sendo a restruturação das redações e cortes de pessoal a principal delas) o fotojornalista parece ganhar maior relevância no mundo social do jornalismo ao qual pertence. De fato, mesmo que parcialmente naturalizada pelo nosso informante, adversidades ligadas ao acúmulo de tarefas provocadas por falta de pessoal que emergem da análise revelam de que maneira os processos de precarização da profissão afetam o trabalho do fotojornalista.

Embora ao longo do século XX a relevância desse profissional tenha aumentado na medida em que sua prática alterou o estatuto da imagem fotográfica na imprensa, seriam necessários outros estudos para verificar se, em decorrência das mudanças dos últimos tempos, houve de fato um aumento nas responsabilidades e mesmo de importância do fotojornalista na rotina produtiva das notícias como um todo no mundo contemporâneo aqui nos referimos aos fotojornalistas ligados a imprensa de cobertura diária, em especial aos jornais. De qualquer maneira, e especificamente no caso do fotojornalista Pedro Ladeira, é notório que sua autonomia para tomar decisões importantes, como avaliar e escolher o que é notícia, aumenta sua importância dentro da configuração atual da Folha de S. Paulo. Contudo, essa autonomia traz consigo um acúmulo de funções e uma precarização de seu trabalho, já que precisa se desdobrar para tentar ser inovador sem deixar de cobrir o maior número de pautas possíveis, se locomovendo com equipamentos pesados e a pé, em grande parte do tempo.

\section{REFERÊNCIAS}


BAUDELAIRE, Charles. 1859. The modern public and photography. In: TRACHTENBERG, Alan. Classic Essays on Photography. Leete's Island Books. New Haven, 1980, p. 83-89.

BECKER, Howard S. Art as collective action. American Sociological Review, 1974a, 39(6): p.767-776. doi: 10.2307/2094151

BECKER, Howard S. Photography and sociology. Studies in Visual Communication, 1974b, 1(1): p.3-23, Recuperado de: http://repository.upenn.edu/svc/vol1/iss 1/3

BECKER, Howard S. Art worlds. Berkeley e Los Angeles, University of California Press, 1982

BECKER, Howard S. Comment parler de la société. Artistes, écrivains, chercheurs et représentations sociales. Paris, La Découverte, 2009.

CASTANHEIRA, Rafael. Rupturas na Fotografia Brasileira: A poética engajada de Claudia Andujar, Miguel Rio Branco e Mario Cravo Neto. 2017. Tese. (Doutorado em Comunicação Social). Faculdade de Comunicação, Universidade de Brasília, Brasília.

DOBAL, Suzana. Sete sintomas de transformação da fotografia documental. Ícone, Pernambuco, V.14, N.1, Agosto de 2012.

FIGARO, Roseli. Perfis e discursos de jornalistas no mundo do trabalho. In: Roseli Figaro (Org.). As mudanças no mundo do trabalho do jornalista. São Paulo: Atlas, 2013, p. 07143.

FLICHY, Patrice. Socio-technological Action and Frame of Reference. Réseaux, 1995, 3(1): p.11-30. doi: 10.3406/reso.1995.3286

GOYANES, Manuel ; RODRIGUEZ-GOMEZ, Eduardo Fco. Presentism in the newsroom: How uncertainty redefines journalists' career expectations. Journalism, First Published April 4, 2018. doi: 10.1177/1464884918767585

KISCHINHEVSKY, Marcelo. O discurso da convergência inevitável: a construção do jornalista multitarefa nas páginas de O Globo. Eptic, 12(3), 2010. Disponível em: https://trapiche.revistas.ufs.br/index.php/eptic/article/view/26. Acesso em 22 jan. 2020.

LE CAM, Florence. Photographs of newsrooms: From the printing house to open space offices. Analyzing the transformation of workspaces and information production. Journalism, 16(1): 134-152, 2015. doi: 10.1177/1464884914558347.

LELO, Thales Vilela. A precarização das condições de trabalho dos jornalistas de São Paulo segmentada por faixas etárias: Uma identidade profissional em risco?. Tempo soc., 31(2): p. 243-261, 2019. doi: 10.11606/0103-2070.ts.2019.146626. 
LOMBARDI, Kátia. Documentário Imaginário: Novas potencialidades na fotografia documental contemporânea. 2007. 172 p. Dissertação (Mestrado em Comunicação Social) Faculdade de Filosofia e Ciências Humanas, UFMG, 2007.

MENGER, Pierre-Michel. Le travail créateur: s'accomplir dans l'incertain. Paris: Gallimard/Seuil, 2009.

MORETZSOHN, Sylvia. Repórter no Volante - O Papel dos Motoristas de Jornal na Produção da Notícia. São Paulo: Publifolha, 2011.

NICOLETTI, Janara; MICK, Jacques. Influências da precarização na qualidade jornalística: Construção de uma matriz de indicadores. Passagens, 9(1): p.127-141, 2018. Disponível em: http://www.periodicos.ufc.br/passagens/article/view/39734. Acesso em 22 jan. 2020.

PEREIRA, Fábio H. As notícias como prática coletiva e convencional: a abordagem beckeriana aplicada aos estudos do jornalismo. Revista Observatório, 4(4), p.389-419, 2018. doi: 10.20873/uft.2447-4266.2018v4n4p389

PEREIRA, Fábio Henrique; KALUME MARANHÃO, Ana Carolina. La concentration multimédia et le nouveau profil du journaliste au Brésil. In: Éric George (Org.). Concentration des médias, changements technologiques et pluralisme de l'information. Sainte-Foy: Presses de l'Université Laval, 2015, p. 159-174.

RENAULT, David. A convergência tecnológica e novo jornalista. Brazilian Journalism Research, 9(2), p. 30-49, 2018. doi: 10.25200/BJR.v9n2. 2013. 575.

ROUILLÉ, ANDRÉ. A fotografia: entre documento e arte contemporânea. Tradução de Constancia Egrejas. São Paulo: Editora Senac São Paulo, 2009.

SILVA, Gislene. Para pensar critérios de noticiabilidade. Estudos em Jornalismo e Mídia, Vol. 2, n. 1, p. 95-107, 2005. DOI: http://dx.doi.org/10.5007/\%25x.

SOUSA, Jorge Pedro. Uma história crítica do fotojornalismo ocidental. Florianópolis: Letras Contemporâneas, 2004.

STRAUSS, Anselm. A Social World Perspective. In N. DENZIN (Org.), Studies in Symbolic Interaction, 1978, vol. 1 p.119-128. Greenwich:, JAI Press.

Recebido 14/02/2020

Aprovado 10/04/2020 


\section{Apêndice 1:}

Autorização do fotojornalista Pedro Ladeira

\section{TERMO DE AUTORIZAÇÃO}

Eu, PEDRO LADEIRA, BRASILEIRO, (ESTADO CIVÍL), portador(a) do RG n. $2(63494 \text {-1) })^{f}$ inscrito(a) no CPF sob o n. $\left.{ }^{\circ} 0049\right) 265(-89$, residente no endereço Rua SQN $2 \pi$ Bf $f$ P log n. 104 , (cidade) - (estado), AUTORIZO o uso e reprodução de fotografias de minha autoria e de informaçōes prestadas ao pesquisador LUZO VINICIUS PEDROSO REIS em observação de campo realizada pelo pesquisador no dia $25 / 06 / 2019$, para fins de pesquisa e divulgação científicas, inclusive artigos eventualmente publicados em revistas científicas nacionais ou internacionais, sem qualquer ônus e em caráter definitivo, desde resguardadas as devidas referências e créditos de autoria.

A presente autorização abrangendo o uso de minhas fotografias e informações coletadas em campo é concedida à título gratuito ao pesquisador em benefício da pesquisa e divulgação científica brasileira ficando vedados usos para outras finalidades, inclusive utilizações comerciais. Por esta ser a expressão da minha vontade, declaro que autorizo o uso acima descrito, sem que nada haja a ser reclamado a título de direitos conexos à imagem ora autorizada ou a qualquer outro, e assino a presente autorização abaixo.

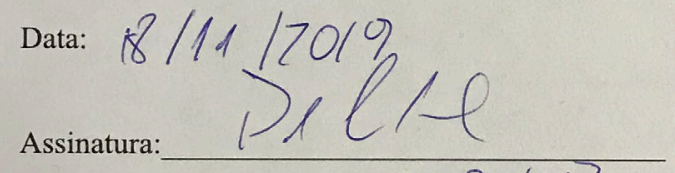

Telefone para contato: $(61) 99981-1698$ 